\title{
Genetic structure, outcrossing rate and heterosis in Astrocaryum mexicanum (tropical palm): implications for evolution and conservation
}

\author{
LUIS E. EGUIARTE*, NIDIA PEREZ-NASSER \& DANIEL PIÑERO \\ Centro de Ecologia, Universidad Nacional Autónoma de México, Apartado Postal 70-275, México, D.F. 04510, México
}

\begin{abstract}
The population genetics of the understory tropical rain forest palm Astrocaryum mexicanum were studied in Los Tuxtlas, Veracruz, Mexico, using enzyme electrophoresis. The percentage of polymorphic loci was 31.8 and the mean expected heterozygosity was 0.153 . Segregation patterns for five polymorphic loci met Mendelian expectations. Outcrossing rates were estimated using single and multilocus methods, and in most cases were not statistically different from 1.0. An excess of heterozygotes, both for seeds and adults, was found, as shown by the fixation indices estimated in 1987 (mean $F$ for adults $=-0.41$, mean $F$ for seeds $=-0.19$ ). Low but significant levels of genetic differentiation were found, especially for adults (mean $F_{\mathrm{st}}$ for adults $=0.040$, mean $F_{\mathrm{st}}$ for seeds $=0.009$ ). There was a positive relationship for adults between trunk growth and an individual's heterozygosity. No significant correlation was found between heterozygosity and fecundity. The genetic structure of $A$. mexicanum appears to be the result of a balance between cross-pollination and long distance movement of pollen by pollinators (beetles) that reduce genetic differentiation among plots, and natural selection that could operate during the long life cycle of this palm, and may increase the genetic differentiation among sites and the proportion of heterozygotes. The relatively high level of genetic variation, low genetic spatial differentiation, excess of heterozygotes, high outcrossing rate and heterosis found in $A$. mexicanum seem to be common in tropical trees. These population genetics characteristics appear not to satisfy the conditions necessary for non-adaptive evolution, a hypothesis commonly invoked to explain high tropical tree diversity. Management and conservation strategies aimed at preserving tropical tree's high intrapopulation genetic variation will probably require the maintenance of large tree populations.
\end{abstract}

Keywords: Astrocaryum mexicanum, genetic structure, heterosis, mating systems, palm, tropical rain forest.

\section{Introduction}

Knowledge about the genetic structure of tropical tree populations can help to explain the evolution of high diversity in the tropics and to design adequate forest conservation and management strategies. Several authors have hypothesized that the high diversity of tropical tree species is a product of non-adaptive speciation resulting from inbreeding and genetic drift (Corner, 1954; Baker, 1959; Federov, 1966; van Steenis, 1969). This inbreeding and genetic drift could

*Present address: Department of Botany and Plant Sciences, University of California, Riverside, California, 92521, U.S.A. be the result of low densities of conspecifics and was based on the assumption that most of the tree species were mainly self-pollinated. This 'non-adaptive' hypothesis assumes that the genetic structure of tropical trees is characterized by high inbreeding (high fixation indices), low effective population sizes and high spatial genetic differentiation, as measured by genetic distance or Wright's $F_{\mathrm{sr}}$. An alternative hypothesis, the 'microniches/equilibrium', originally proposed by Dobzhansky (1950), contends that the tropical tree diversity results from adaptation of tree populations to very specific niches defined by both biotic and abiotic components (pollinators, seed dispersors, soil, light, succession, seed predators, etc.) 
(Janzen, 1970; Connell, 1978; Hubbell, 1979; Denslow, 1987; Bawa, 1990). This hypothesis requires low inbreeding and high effective population sizes.

The genetic structure of tree populations imposes constraints on management and conservation strategies. If tropical trees usually occur in small, inbred populations, as the non-adaptive hypothesis predicts, then a species could be preserved with few individuals from each population but collection from many different populations and ex situ preservation could be practical and feasible (Frankel \& Soulé, 1981; Eguiarte \& Piñero, 1990). Conversely, if tropical trees present high effective population sizes and low inbreeding (as the microniches hypothesis suggests), then the deleterious effects of maintaining low populations should be severe both in the short term, because of the inbreeding depression, and long term, because of genetic drift (Franklin, 1980; Eguiarte \& Piñero, 1990). If this last case is true, viable conservation proposals should contemplate the maintenance of large ecological preserves, and ex situ conservation becomes impossible (Frankel \& Soulé, 1981; Eguiarte \& Piñero, 1990).

Population genetics information for tropical tree species is scarce and fragmentary. Some studies report data on levels of genetic variation (Gan et al., 1977, 1981; Hamrick \& Loveless, 1986), while others analyse the genetic structure (Buckley et al., 1988; Hamrick \& Loveless, 1989), or the mating system (O’Malley \& Bawa, 1987; O'Malley et al., 1988; Hamrick \& Loveless, 1989).

The population ecology and reproductive biology of the monoecious understory tropical palm Astrocaryum mexicanum are relatively well known (Piñero et al., 1984, 1986; Sarukhán et al., 1984; Búrquez et al., 1987). Here we present a comprehensive study of its genetic variation, outcrossing rates, genetic structure and heterosis using allozyme marker genes. We compare these parameters with data from other tropical tree populations and argue that available data does not provide support for the non-adaptive evolution scenario for tropical tree diversity.

\section{Materials and methods}

\section{Study site}

Field work was conducted at the Estación de Biología Tropical Los Tuxtlas, of the National University of Mexico (UNAM). It is located in the coastal side of the range of Los Tuxtlas, State of Veracruz, Mexico (long. between $95^{\circ} 04^{\prime}$ and $95^{\circ} 09^{\prime} \mathrm{N}$, lat. between $18^{\circ} 34^{\prime}$ and $\left.18^{\circ} 36^{\prime} \mathrm{W}\right)$. The vegetation and climate have been described by Piñero et al. (1977) and Bongers et al. (1988).

\section{Seed collections}

In $A$. mexicanum, the adult plants present from 0 to 5 infructescences in a given year, each containing a mean of 23 fruits, every fruit containing only one seed (Búrquez et al., 1987).

Twenty seeds from a single infructescence were collected for electrophoresis from each palm reproducing in a given year inside four permanent plots $(20 \times 30 \mathrm{~m})$ of contrasting densities of $A$. mexicanum in a virgin rain forest [A and B plots are high density and $\mathrm{C}$ and $\mathrm{CC}$ are low density plots, Table 1 (Piñero et al., 1977, 1984)], plus a 10-m strip on each side of every plot, producing plots of $40 \times 50 \mathrm{~m}$. In 1985 and 1988 seeds were collected from plot B only; in 1987 plots A, $\mathrm{B}, \mathrm{C}$ and $\mathrm{CC}$ were collected. A larger plot $(50 \times 60 \mathrm{~m})$ was collected for the site B in 1988, in order to have a larger sample that year. The mean distance between plots was $365 \mathrm{~m}$ (Table 1). Data on the number of infructescences produced from 1975 to 1986 , and on the increase in height from 1975 to 1982 (M. MartínezRamos et al. unpubl., data) were available for roughly one-third of the adults from which seeds were collected (90 adults for inflorescences, 87 for growth). Collected seeds were kept alive by maintaining them in humid soil from Los Tuxtlas or in humid agrolite until used.

Table 1 Abundances of Astrocaryum mexicanum in permanent plots [ $600 \mathrm{~m}^{2}$, Piñero et al. $\left.(1977,1984)\right]$, distances among plots and number of collected adults for this study in Los Tuxtlas, Veracruz, Mexico

\begin{tabular}{|c|c|c|c|c|}
\hline & \multicolumn{4}{|c|}{ Plots } \\
\hline & A & B & $\mathrm{C}$ & $\mathrm{CC}$ \\
\hline \multicolumn{5}{|l|}{ Individuals in 1975} \\
\hline Seedlings & 261 & 150 & 54 & 54 \\
\hline Juveniles & 65 & 60 & 25 & 18 \\
\hline Adults & 101 & 88 & 36 & 49 \\
\hline \multicolumn{5}{|c|}{ Distances among pairs of plots $(\mathrm{m})$} \\
\hline A & & 250 & 360 & 200 \\
\hline B & & & 450 & 370 \\
\hline $\mathrm{C}$ & & & & 560 \\
\hline \multicolumn{5}{|c|}{ Number of collected adults for this study } \\
\hline 1985 inside plot & - & 20 & - & - \\
\hline 1985 around plot* & - & 51 & - & - \\
\hline 1987 inside plot & 32 & 28 & 20 & 22 \\
\hline 1987 around plot* & 40 & 53 & 22 & 23 \\
\hline 1988 inside plot & - & 21 & - & - \\
\hline 1988 around plot $\dagger$ & - & 77 & - & - \\
\hline
\end{tabular}

*Strip of $1400 \mathrm{~m}^{2}$ around plot. † Strip of $2400 \mathrm{~m}^{2}$ around plot. 


\section{Controlled crosses}

Controlled crosses were performed in 1988 with the methods described in Búrquez et al. (1987). We crossed 11 mothers with four fathers (one father was used in seven pollinations, another in two and two others in only one pollination), to analyse the segregation patterns for five loci $(M d h-1,6-P g d-1, P g i-1$, $A d h-1, L a p-2)$ used to evaluate genetic structure and outcrossing rates.

\section{Electrophoretic procedures}

Fresh embryos were ground in two drops of gel buffer, adsorbed onto filter paper wicks and inserted into a $12.5 \%$ starch gel (Sigma Chemical Co.) for horizontal electrophoresis. The buffers used were histidine $\mathrm{pH}$ 7.0, Poulik pH 8.1/8.6 (Piñero \& Eguiarte, 1988) and Tris-citrate pH 8.0 (Selander et al., 1986). Enzyme stain recipes were used as described by Vallejos (1983) and Piñero \& Eguiarte (1988). The 11-enzyme systems studied were: acid phosphatase $(\mathrm{ACPH})$, isocitric dehydrogenase (IDH), shikimic dehydrogenase (SDH), xanthine dehydrogenase (XHD), alcohol dehydrogenase $(\mathrm{ADH})$, esterase (Est), leucine aminopetidase (LAP), malate dehydrogenase (MDH), 6-phosphogluconate dehydrogenase (6-PGD), phosphoglucoisomerase (PGI) and phosphoglucomutase (PGM). We used five loci (Mdh-1, 6Pgd-1, Pgi-1, Adh-1, Lap-2) to study the genetic structure and outcrossing rates for different plots and years.

\section{Data analyses}

A sample of seeds collected from all plots in 1987 was used to estimate the genetic variation parameters (Brown \& Weir, 1983; Hedrick, 1983). Single and multilocus outcrossing rate $(t)$ estimates, their standard errors and maternal genotypes were estimated with Ritland \& Jain's (1981) mixed mating model method, using Ritland's (1990) MLT program. Violations of the mixed mating model were analysed using Ritland's (1983) approach. Allelic frequencies for both adults and seeds, Nei (1972) multilocus genetic identities $(I)$ and distances $(D)$ between all pairs of plots, fixation indices and the Wright's $F$-statistics (Wright, 1965) were obtained with Nei's (1987) formulas using a program developed by Gerardo Coello and Ana María Escalante. Confidence intervals at 95 per cent for the $F$ statistics were calculated by a jackknife procedure (Weir, 1990).

Parametric and non-parametric regressions were performed (Sokal \& Rohlf, 1969) on the number of infructescences produced from 1975 to 1986 , on increases in height from 1975 to 1982 , and on height in 1975 , using the number of heterozygous loci per individual as the independent variable. As growth and fecundity may be correlated with size, ANOvA were done with the residuals of the regression of growth against height in 1975, and with the residuals of the regression between fecundity against initial height in 1975 , in both cases using the number of heterozygous loci as classificatory variable.

\section{Results}

\section{Levels of genetic variation}

Four of the 11 assayed enzymes were monomorphic (ACPH, and $\mathrm{XDH}$ with two 'loci' each, and IDH and SDH with one 'locus' each) and seven were polymorphic for at least one 'locus' (Table 2). We analysed 22 putative loci of which seven were polymorphic. We found two alleles for all but one of the polymorphic loci, Lap-2, for which we found three alleles. At Los Tuxtlas, $A$. mexicanum has $31.8 \%$ polymorphic loci $(P), 1.36$ and 2.14 effective alleles considering all loci and only the polymorphic ones respectively, and a mean expected heterozygosity $(H)$ of 0.153 (Hedrick, 1983).

\section{Controlled crosses}

For the five loci analysed most of the crosses showed a Mendelian segregation pattern (due to the small family sizes, all the crosses for each class were pooled, Table 3 ), with the exception of the crosses among heterozygotes for Pgi-1, where there appears to be an excess of heterozygotes $\left(\chi_{[2]}^{2}=7.47, P<0.05\right)$.

\section{Mating system}

Both single and multilocus estimates of outcrossing rate, when considered for different plots and different years, were close to one (Table 4). The mean single locus estimate for all enzymes and plots in 1987 was 1.030 , and for plot B the average over 3 years was 1.098. The multilocus outcrossing rates varied less with a mean of 1.011 for the 1987 data and 0.997 for plot B over 3 years. All multilocus estimates except one (plot CC, Mdh-1; Table 4) were not significantly different from one. In $48 \%$ of the cases we found departures from the mixed mating model, using Ritland's (1983) Chi-square method (Table 5). These departures have little effect on the estimates when using multilocus methods to obtain the outcrossing rate (Ritland, 1983; Brown et al., 1985). 
Table 2 Genetic variation in A. mexicanum at Los Tuxtlas, Veracruz, Mexico, in 1987. Buffers in which enzymes were assayed were Poulik $(\mathrm{P})$ and histidine $(\mathrm{H})$ (Piñero \& Eguiarte, 1988)

\begin{tabular}{llll}
\hline & $\begin{array}{l}\text { Sample } \\
\text { size }\end{array}$ & $\begin{array}{l}\text { Locus } \\
\text { number }\end{array}$ & $\begin{array}{l}\text { Allelic } \\
\text { frequencies }\end{array}$ \\
\hline Alcohol dehydrogenase, ADH (H) & 963 & 1 & $0.529,0.471$ \\
Esterase, EST (H) & 674 & 1 & 1.0 \\
& 674 & 2 & 1.0 \\
& 674 & 3 & $0.437,0.563$ \\
Leucine aminopeptidase, LAP (H) & 674 & 4 & 1.0 \\
& 963 & 1 & 1.0 \\
Malate dehydrogenase, MDH (H) & 963 & 2 & $0.5,0.44,0.06$ \\
& 963 & 1 & $0.678,0.322$ \\
6-phosphogluconate dehydrogenase, 6-PGD (H) & 963 & 1 & $0.543,0.457$ \\
Phosphoglucoisomerase, PGI (H) & 963 & 1 & $0.586,0.414$ \\
& 963 & 2 & 1.0 \\
Phosphoglucomutase, PGM (P) & 963 & 3 & 1.0 \\
& 40 & 1 & 1.0 \\
& 40 & 2 & $0.500,0.500$ \\
\hline
\end{tabular}

Table 3 Segregation patterns for five loci in A. mexicanum at Los Tuxtlas, Veracruz, Mexico. Expectations assuming Mendelian proportions are shown in parentheses. Chi-squares were done with Yates continuity correction for small samples (Sokal \& Rohlf, 1969)

\begin{tabular}{|c|c|c|c|c|c|c|}
\hline \multirow[b]{2}{*}{ Locus } & \multirow[b]{2}{*}{ Cross } & \multicolumn{3}{|c|}{ Progeny genotypes } & \multirow[b]{2}{*}{$\chi^{2}$} & \multirow[b]{2}{*}{ d.f. } \\
\hline & & 11 & 12 & 22 & & \\
\hline$M d h-1$ & $12 \times 12$ & $17(12.75)$ & $21(25.5)$ & $13(12.75)$ & 1.74 & 2 \\
\hline$M d h-1$ & $11 \times 12$ & $54(46)$ & $38(46)$ & 0 & 2.45 & 1 \\
\hline$M d h-1$ & $11 \times 22$ & 0 & 6 & 0 & & \\
\hline $6 P g d-1$ & $12 \times 12$ & $29(23.5)$ & $44(47)$ & $21(23.5)$ & 1.29 & 2 \\
\hline 6Pgd-1 & $11 \times 12$ & $4(4.5)$ & $5(4.5)$ & 0 & 0 & 1 \\
\hline $6 P d g-1$ & $22 \times 12$ & 0 & $7(5.5)$ & $4(5.5)$ & 0.36 & 1 \\
\hline$P g i-1$ & $12 \times 12$ & $28(30.75)$ & $76(61.5)$ & $19(30.75)$ & $7.47^{*}$ & 2 \\
\hline$P g i-1$ & $11 \times 12$ & $27(34)$ & $41(34)$ & 0 & 2.49 & 1 \\
\hline Adh-1 & $12 \times 12$ & $43(39.5)$ & $76(79)$ & $39(39.5)$ & 0.31 & 2 \\
\hline Adh-1 & $12 \times 11$ & $10(12)$ & $14(12)$ & 0 & 0.38 & 1 \\
\hline Lap-2 & $12 \times 12$ & $6(7)$ & $19(14)$ & $3(7)$ & 3.23 & 2 \\
\hline Lap-2 & $12 \times 11$ & $45(53.5)$ & $62(53.5)$ & 0 & 2.39 & 1 \\
\hline Lap-2 & $12 \times 22$ & 0 & $10(11)$ & $12(11)$ & 0.05 & 1 \\
\hline
\end{tabular}

${ }^{*} P<0.05$.

\section{Genetic differentiation}

Difference between plots for allelic frequencies were relatively small for reproductive adults and even smaller for seeds (Table 6). Workman \& Niswander (1970) chi-square heterogeneity in variances test suggests that in adults the differences in allelic frequencies, although small, were significant for all loci except
Pgi-1 (Table 6). For seeds we found significant heterogeneity in allelic frequencies only for $M d h-1$, where allele 1 had higher frequencies in both low density plots (C and $\mathrm{CC}$ ) (Table 7). This indicates that the pollen allelic pool was different from the adult local allelic frequencies and indicates extensive pollen movement. Genetic identities in 1987 for pairs of plots for the five selected loci were high in reproductive adults 
Table 4 Single and multilocus outcrossing rates $(t)$ estimates for $A$. mexicanum. $95 \%$ confidence intervals are shown in parentheses

\begin{tabular}{lcccccc}
\hline & \multicolumn{7}{l}{ Year and plot } & & & & \\
\cline { 2 - 7 } Locus & $1985 \mathrm{~B}$ & $1987 \mathrm{~A}$ & $1987 \mathrm{~B}$ & $1987 \mathrm{C}$ & $1987 \mathrm{CC}$ & $1988 \mathrm{~B}$ \\
\hline Mdh-1 & & 1.105 & 1.040 & 0.833 & 0.558 & 1.145 \\
& & $(0.194)$ & $(0.276)$ & $(0.473)$ & $(0.263)$ & $(0.198)$ \\
6Pgd-1 & 0.942 & 0.806 & 1.212 & 0.539 & 1.311 & 0.920 \\
& $(0.221)$ & $(0.372)$ & $(0.114)$ & $(0.780)$ & $(0.206)$ & $(0.204)$ \\
Pgi-1 & & 1.181 & 1.363 & 0.811 & 1.263 & 1.388 \\
& & $(0.255)$ & $(0.210)$ & $(0.560)$ & $(0.233)$ & $(0.292)$ \\
Adh-1 & & 1.091 & 0.910 & 1.196 & 0.893 & 0.971 \\
& & $(0.198)$ & $(0.319)$ & $(0.192)$ & $(0.337)$ & $(0.171)$ \\
Lap-2 & 1.080 & 1.179 & 1.160 & 1.036 & 1.110 & 1.043 \\
& $(0.149)$ & $(0.165)$ & $(0.167)$ & $(0.145)$ & $(0.157)$ & $(0.148)$ \\
Mean $t$ & 0.956 & 1.077 & 1.078 & 1.070 & 1.068 & 1.045 \\
& $(0.176)$ & $(0.065)$ & $(0.039)$ & $(0.065)$ & $(0.666)$ & $(0.053)$ \\
Multilocus $t$ & 0.933 & 1.050 & 0.992 & 1.018 & 0.985 & 1.007 \\
& $(0.174)$ & $(0.066)$ & $(0.039)$ & $(0.063)$ & $(0.065)$ & $(0.053)$ \\
\hline
\end{tabular}

Table 5 Chi-square for deviations from the expected values according to the mixed mating model (Ritland, 1983), for A. mexicanum. Degrees of freedom in parentheses; as they are approximate, we used an $\alpha$ of 0.01 , as suggested by Ritland (1983)

\begin{tabular}{|c|c|c|c|c|c|c|}
\hline \multirow[b]{2}{*}{ Locus } & \multicolumn{6}{|c|}{ Year and plot } \\
\hline & $1985 \mathrm{~B}$ & 1987 A & 1987 B & $1987 \mathrm{C}$ & $1987 \mathrm{CC}$ & $1988 \mathrm{~B}$ \\
\hline$M d h-1$ & & $4.23(1)$ & $7.07(1)^{*}$ & $6.98(1)^{*}$ & $17.53(1)^{*}$ & $5.54(1)$ \\
\hline $6 P g d-1$ & $1.26(1)$ & $3.60(1)$ & $4.05(1)$ & $8.58(1)^{*}$ & $4.66(1)$ & $4.09(1)$ \\
\hline Pgi-1 & & $8.23(1)^{*}$ & $3.19(1)$ & $2.31(1)$ & $7.41(1)^{*}$ & $4.30(1)$ \\
\hline Adh-1 & & $6.24(1)$ & $18.39(1)^{*}$ & $5.84(1)$ & $13.15(1)^{*}$ & $14.87(1)^{*}$ \\
\hline Lap-2 & $3.90(1)$ & $31.48(9)^{*}$ & $45.72(9)^{*}$ & $17.69(9)$ & $45.13(1)^{*}$ & $36.96(9)^{*}$ \\
\hline
\end{tabular}

${ }^{*} P<0.01$.

(Table 8 , mean $I=0.9764 \pm 0.0116$ s.d.) and higher in their progeny (Table 8 , mean $I=0.9944 \pm 0.0038$ s.d.)

\section{Fixation indices and F-statistics}

In most cases (94.4\%) the fixation indices were negative, for both adults and seeds, and differed significantly from random maing expectations in $66.7 \%$ of the cases (Table 9), being significantly positive in only one (plot CC, 1987, seeds, $M d h-1$ ). Both adults and seeds show an excess of heterozygous individuals (mean $F 1987$ adults $=-0.411$, seeds $=-0.186$ ), which suggests strong selection favouring heterozygotes. The excess of heterozygotes is significantly greater in adults than in seeds (Wilcoxon paired samples test $T=346, P=0.0002)$. This trend indicates that increased survivorship of the heterozygous individuals from the seeds to the reproductive adult stage is likely.

$F_{\text {is }}$ is significantly negative for all loci both in adults and seeds (Table 10), as was expected from the fixation indices. $F_{\text {st }}$ estimates are small but significantly different from zero for all loci (except Pgi-1 for adults) in both adults and seeds (Table 10). $F_{\text {st }}$ is significantly higher in the adults than in the seeds (Table 10). $F_{\text {it }}$ estimates are significantly negative in all cases, except in $M d h-1$ for seeds (Table 10).

\section{Heterosis}

Table 11 shows a correlation matrix of the infructescences produced in 13 years (1975-1987), trunk 
Table 6 Allelic frequencies for adults of A. mexicanum and Chi-square tests for heterogeneity in allelic frequencies among plots (Workman \& Niswander, 1970). 95\% confidence intervals are shown in parentheses (Brown \& Weir, 1983;

Richardson et al., 1986)

\begin{tabular}{|c|c|c|c|c|c|c|c|}
\hline \multirow[b]{2}{*}{ Locus } & \multirow[b]{2}{*}{ Allele } & \multicolumn{4}{|l|}{ Plot } & \multirow[b]{2}{*}{$\chi^{2}$ (d.f.) } & \multirow[b]{2}{*}{$P<$} \\
\hline & & A & B & $\mathrm{C}$ & $\mathrm{CC}$ & & \\
\hline$M d h-1$ & 1 & $\begin{array}{c}0.854 \\
(0.057)\end{array}$ & $\begin{array}{c}0.771 \\
(0.064)\end{array}$ & $\begin{array}{c}0.929 \\
(0.055)\end{array}$ & $\begin{array}{c}0.833 \\
(0.077)\end{array}$ & $10.4(3)$ & 0.02 \\
\hline$M d h-1$ & 2 & $\begin{array}{c}0.146 \\
(0.057)\end{array}$ & $\begin{array}{c}0.228 \\
(0.064)\end{array}$ & $\begin{array}{c}0.929 \\
(0.055)\end{array}$ & $\begin{array}{c}0.833 \\
(0.077)\end{array}$ & & \\
\hline $6 P g d-1$ & 1 & $\begin{array}{c}0.694 \\
(0.075)\end{array}$ & $\begin{array}{c}0.617 \\
(0.074)\end{array}$ & $\begin{array}{c}0.452 \\
(0.106)\end{array}$ & $\begin{array}{c}0.722 \\
(0.092)\end{array}$ & $17.33(3)$ & 0.005 \\
\hline $6 P g d-1$ & 2 & $\begin{array}{c}0.306 \\
(0.075)\end{array}$ & $\begin{array}{c}0.383 \\
(0.074)\end{array}$ & $\begin{array}{c}0.548 \\
(0.106)\end{array}$ & $\begin{array}{c}0.278 \\
(0.092)\end{array}$ & & \\
\hline$P g i-1$ & 1 & $\begin{array}{c}0.847 \\
(0.059)\end{array}$ & $\begin{array}{c}0.815 \\
(0.060)\end{array}$ & $\begin{array}{c}0.786 \\
(0.078)\end{array}$ & $\begin{array}{c}0.767 \\
(0.087)\end{array}$ & $2.74(3)$ & 0.50 \\
\hline$P g i-1$ & 2 & $\begin{array}{c}0.153 \\
(0.059)\end{array}$ & $\begin{array}{c}0.185 \\
(0.060)\end{array}$ & $\begin{array}{c}0.214 \\
(0.078)\end{array}$ & $\begin{array}{c}0.233 \\
(0.087)\end{array}$ & & \\
\hline$A d h-1$ & 1 & $\begin{array}{c}0.743 \\
(0.071)\end{array}$ & $\begin{array}{c}0.506 \\
(0.077)\end{array}$ & $\begin{array}{c}0.654 \\
(0.101)\end{array}$ & $\begin{array}{c}0.500 \\
(0.103)\end{array}$ & $23.05(3)$ & 0.005 \\
\hline$A d h-1$ & 2 & $\begin{array}{c}0.257 \\
(0.071)\end{array}$ & $\begin{array}{c}0.494 \\
(0.077)\end{array}$ & $\begin{array}{c}0.345 \\
(0.101)\end{array}$ & $\begin{array}{c}0.500 \\
(0.103)\end{array}$ & & \\
\hline$L a p-2$ & 1 & $\begin{array}{c}0.556 \\
(0.081)\end{array}$ & $\begin{array}{c}0.444 \\
(0.076)\end{array}$ & $\begin{array}{c}0.298 \\
(0.097)\end{array}$ & $\begin{array}{c}0.333 \\
(0.097)\end{array}$ & $23.91(6)$ & 0.005 \\
\hline Lap-2 & 2 & $\begin{array}{c}0.430 \\
(0.081)\end{array}$ & $\begin{array}{c}0.543 \\
(0.076)\end{array}$ & $\begin{array}{c}0.642 \\
(0.102)\end{array}$ & $\begin{array}{c}0.611 \\
(0.100)\end{array}$ & & \\
\hline Lap-2 & 3 & $\begin{array}{c}0.014 \\
(0.019)\end{array}$ & $\begin{array}{c}0.012 \\
(0.017)\end{array}$ & $\begin{array}{c}0.054 \\
(0.051)\end{array}$ & $\begin{array}{c}0.055 \\
(0.047)\end{array}$ & & \\
\hline
\end{tabular}

height increase in 7 years (1975-1982), height of the palms in 1975 (a measure of their size), and the number of heterozygous loci per individual. The only significant correlations are between growth and heterozygosity, and between initial height and fecundity. To control for the correlation between size and fecundity, two standardized ANOvA were done using the residuals of the regression of infructescence production and height in 1975 in one, and the residuals of the regression of trunk height increase and height in 1975 in the other. The number of heterozygous loci for both ANOvA was the classificatory variable. With the standardized data we found a significant positive relation between the number of heterozygous loci and the deviation from average growth for reproductive adults of a given size (ANOVA $F_{4,82}=2.524 ; P=0.047$ ). There was no significant relationship between the number of heterozygous enzymes with the deviation from the average number of infructescences produced in 13 (19751987) years for a given size plant $\left(F_{4,85}=0.944\right.$; $P=0.443)$ or with initial height $\left(F_{4,82}=0.508\right.$; $P=0.730$ ).

\section{Discussion}

Given the high phenotypic variability described in the Los Tuxtlas A. mexicanum population (Sarukhán et al., 1984), and the fact that most plants, especially trees, show high levels of genetic variation (Hamrick et al., 1979; Hamrick \& Godt, 1989), we expected high levels of electrophoretically detectable genetic variation. Our results confirm this expectation.

Originally we expected a high outcrossing rate $(t)$ for A. mexicanum, as Búrquez et al. (1987) found that although individuals are self-compatible, self-pollinations produced $23 \%$ seeds/ovules, relative to crosspollinations. The temporal and spatial separation of the female and male flowers in a given inflorescence (Piñero \& Sarukhán, 1982; Búrquez et al., 1987), should contribute to a high outcrossing rate. We found that for both single and multilocus estimates the outcrossing rate of $A$. mexicanum was not significantly different from one, indicating no detectable self-fertilization. The high outcrossing rate found may result from the peculiar reproductive behaviour of $A$. 
Table 7 Allelic frequencies for seeds of $A$. mexicanum and Chi-square tests for heterogeneity in allelic frequencies among plots (Workman \& Niswander, 1970). $95 \%$ confidence intervals are shown in parentheses (Brown \& Weir, 1983;

Richardson et al., 1986)

\begin{tabular}{|c|c|c|c|c|c|c|c|}
\hline \multirow[b]{2}{*}{ Locus } & \multirow[b]{2}{*}{ Allele } & \multicolumn{4}{|l|}{ Plot } & \multirow[b]{2}{*}{$\chi^{2}$ (d.f.) } & \multirow[b]{2}{*}{$P<$} \\
\hline & & A & B & $\mathrm{C}$ & $\mathrm{CC}$ & & \\
\hline$M d h-1$ & 1 & $\begin{array}{c}0.644 \\
(0.051)\end{array}$ & $\begin{array}{c}0.619 \\
(0.049)\end{array}$ & $\begin{array}{c}0.782 \\
(0.063)\end{array}$ & $\begin{array}{c}0.762 \\
(0.057)\end{array}$ & $37.51(3)$ & 0.005 \\
\hline$M d h-1$ & 2 & $\begin{array}{c}0.355 \\
(0.051)\end{array}$ & $\begin{array}{c}0.389 \\
(0.049)\end{array}$ & $\begin{array}{c}0.218 \\
(0.063)\end{array}$ & $\begin{array}{c}0.238 \\
(0.057)\end{array}$ & & \\
\hline $6 P g d-1$ & 1 & $\begin{array}{c}0.515 \\
(0.054)\end{array}$ & $\begin{array}{c}0.574 \\
(0.050)\end{array}$ & $\begin{array}{c}0.508 \\
(0.077)\end{array}$ & $\begin{array}{c}0.549 \\
(0.066)\end{array}$ & $5.68(3)$ & 0.25 \\
\hline $6 P g d-1$ & 2 & $\begin{array}{c}0.485 \\
(0.054)\end{array}$ & $\begin{array}{c}0.426 \\
(0.050)\end{array}$ & $\begin{array}{c}0.492 \\
(0.077)\end{array}$ & $\begin{array}{c}0.451 \\
(0.066)\end{array}$ & & \\
\hline Pgi-1 & 1 & $\begin{array}{c}0.617 \\
(0.039)\end{array}$ & $\begin{array}{c}0.583 \\
(0.050)\end{array}$ & $\begin{array}{c}0.563 \\
(0.076)\end{array}$ & $\begin{array}{c}0.558 \\
(0.066)\end{array}$ & $4.23(3)$ & 0.30 \\
\hline Pgi-1 & 2 & $\begin{array}{c}0.383 \\
(0.039)\end{array}$ & $\begin{array}{c}0.417 \\
(0.050)\end{array}$ & $\begin{array}{c}0.437 \\
(0.076)\end{array}$ & $\begin{array}{c}0.442 \\
(0.066)\end{array}$ & & \\
\hline Adh-1 & 1 & $\begin{array}{c}0.537 \\
(0.054)\end{array}$ & $\begin{array}{c}0.545 \\
(0.050)\end{array}$ & $\begin{array}{c}0.550 \\
(0.076)\end{array}$ & $\begin{array}{c}0.476 \\
(0.066)\end{array}$ & $6.12(3)$ & 0.25 \\
\hline Adh-1 & 2 & $\begin{array}{c}0.463 \\
(0.054)\end{array}$ & $\begin{array}{c}0.454 \\
(0.050)\end{array}$ & $\begin{array}{c}0.450 \\
(0.076)\end{array}$ & $\begin{array}{c}0.524 \\
(0.066)\end{array}$ & & \\
\hline Lap-2 & 1 & $\begin{array}{c}0.529 \\
(0.054)\end{array}$ & $\begin{array}{c}0.494 \\
(0.050)\end{array}$ & $\begin{array}{c}0.462 \\
(0.077)\end{array}$ & $\begin{array}{c}0.490 \\
(0.066)\end{array}$ & $9.99(6)$ & 0.25 \\
\hline Lap-2 & 2 & $\begin{array}{c}0.410 \\
(0.052)\end{array}$ & $\begin{array}{c}0.464 \\
(0.050)\end{array}$ & $\begin{array}{c}0.458 \\
(0.076)\end{array}$ & $\begin{array}{c}0.439 \\
(0.066)\end{array}$ & & \\
\hline Lap-2 & 3 & $\begin{array}{c}0.061 \\
(0.025)\end{array}$ & $\begin{array}{c}0.042 \\
(0.020)\end{array}$ & $\begin{array}{c}0.080 \\
(0.042)\end{array}$ & $\begin{array}{c}0.070 \\
(0.034)\end{array}$ & & \\
\hline
\end{tabular}

Table 8 Unbiased genetic distances (above the diagonal) and identities (below the diagonal) for adults and seeds (Nei, 1972, 1987) between pairs of plots

\begin{tabular}{|c|c|c|c|c|}
\hline & \multicolumn{4}{|l|}{ Sites } \\
\hline & A & $\mathrm{B}$ & $\mathrm{C}$ & $\mathrm{CC}$ \\
\hline A adults & & 0.0220 & 0.0373 & 0.0295 \\
\hline A seeds & & 0.0015 & 0.0067 & 0.0072 \\
\hline $\mathrm{B}$ adults & 0.9783 & & 0.0245 & 0.0028 \\
\hline B seeds & 0.9985 & & 0.0095 & 0.0086 \\
\hline$C$ adults & 0.9633 & 0.9758 & & 0.0283 \\
\hline C seeds & 0.9933 & 0.9905 & & 0.0003 \\
\hline $\mathrm{CC}$ adults & 0.9710 & 0.9972 & 0.9721 & \\
\hline CC seeds & 0.9929 & 0.9914 & 0.9997 & \\
\hline
\end{tabular}

mexicanum and the high mobility of beetle pollinators (Búrquez et al., 1987).

In about half of the cases we found deviations from the expectations of the mixed mating model. Similar deviations have been reported in most studies (Smyth \& Hamrick, 1984; O’Malley \& Bawa, 1987; O'Malley et al. 1988; Sampson et al., 1989) and are not surprising given the constraints of the mixed mating model (Brown et al., 1985). In A. mexicanum there are five possible causes for departure from the expectations of the mixed mating model.

1 Allelic frequencies in the pollen may be biased because of a non-random sample of pollen donors. This may be important in A. mexicanum, considering that in a given year only a fraction (about $31 \%$ ) of the total of reproductive adults produce flowers (Piñero \& Sarukhán, 1982).

2 Matings may be correlated in the sense of Schoen \& Clegg (1984, 1986); the pollen donors of an infructescence may be few with respect to the total set of potential fathers. Correlated mating may also occur in $A$. mexicanum because of the relatively low number of individuals that flower in a given day (Búrquez et al., 1987).

3 Segregation distortion may occur at certain loci. We cannot rule out this probability because the sample size in the controlled crosses was low (Ellstrand \& Devlin, 1989). 
Table 9 Fixation indices for adults and seeds in A. mexicanum. 95\% confidence intervals shown in parentheses (Rasmussen, 1964; Weir, 1990)

\begin{tabular}{|c|c|c|c|c|c|c|}
\hline \multirow[b]{2}{*}{ Locus } & \multicolumn{6}{|c|}{ Year and plot } \\
\hline & $1985 \mathrm{~B}$ & $1987 \mathrm{~A}$ & $1987 \mathrm{~B}$ & $1987 \mathrm{C}$ & 1987 CC & $1988 \mathrm{~B}$ \\
\hline$M d h-1$ adults & & $\begin{array}{l}-0.1707 \\
(0.1109) \\
=\dagger\end{array}$ & $\begin{array}{l}-0.2960^{*} \\
(0.1285) \\
=\end{array}$ & $\begin{array}{l}-0.0769 \\
(0.0960) \\
=\end{array}$ & $\begin{array}{l}-0.2000 \\
<^{(0.1480)}\end{array}$ & $\begin{array}{r}-0.2683^{*} \\
(0.1255) \\
=\end{array}$ \\
\hline$M d h-1$ seeds & & $\begin{array}{r}-0.2694^{*} \\
(0.1037)\end{array}$ & $\begin{array}{c}-0.0849 \\
(0.1037)\end{array}$ & $\begin{array}{c}-0.0827 \\
(0.1628)\end{array}$ & $\begin{array}{r}+0.1967^{*} \\
(0.1967)\end{array}$ & $\begin{array}{r}-0.0650 \\
(0.0940)\end{array}$ \\
\hline $6 P g d-1$ adults & $\begin{array}{l}-0.3793 \\
(0.2765) \\
=\end{array}$ & $\begin{array}{l}-0.4400^{*} \\
< \\
<\end{array}$ & $\begin{array}{l}-0.6200^{*} \\
<^{(0.1427)}\end{array}$ & $\begin{array}{l}-0.8261^{*} \\
<^{(0.1580)}\end{array}$ & $\begin{array}{l}-0.3845^{*} \\
(0.1849) \\
=\end{array}$ & $\begin{array}{l}-0.7103^{*} \\
<^{(0.1493)}\end{array}$ \\
\hline $6 P g d-1$ seeds & $\begin{array}{c}+0.0391 \\
(0.1999)\end{array}$ & $\begin{array}{c}-0.0963 \\
(0.1220)\end{array}$ & $\begin{array}{c}-0.0165 \\
(0.1055)\end{array}$ & $\begin{array}{r}-0.1600 \\
(0.1765)\end{array}$ & $\begin{array}{r}-0.1369^{*} \\
(0.1344)\end{array}$ & $\begin{array}{r}-0.0163 \\
(0.0940)\end{array}$ \\
\hline$P g i-1$ adults & & $\begin{array}{l}-0.1803 \\
(0.1126) \\
=\end{array}$ & $\begin{array}{l}-0.2273^{*} \\
=(0.1160) \\
=\end{array}$ & $\begin{array}{l}-0.2727 \\
= \\
=\end{array}$ & $\begin{array}{l}-0.3043^{*} \\
=(0.1720) \\
=\end{array}$ & $\begin{array}{l}-0.2000^{*} \\
(0.1126) \\
=\end{array}$ \\
\hline Pgi-1 seeds & & $\begin{array}{r}-0.3031^{*} \\
(0.1030)\end{array}$ & $\begin{array}{r}-0.3212^{*} \\
(0.0980)\end{array}$ & $\begin{array}{r}-0.2979^{*} \\
(0.1686)\end{array}$ & $\begin{array}{r}-0.3189^{*} \\
(0.1285)\end{array}$ & $\begin{array}{r}-0.2963^{*} \\
(0.0898)\end{array}$ \\
\hline$A d h-1$ adults & & $\begin{array}{l}-0.3458^{*} \\
(0.1427) \\
=\end{array}$ & $\begin{array}{l}-0.8274^{*} \\
< \\
<\end{array}$ & $\begin{array}{l}-0.4219^{*} \\
= \\
=\end{array}$ & $e^{-0.7330^{*}}$ & $\begin{array}{l}-0.7027^{*} \\
e^{(0.1543)}\end{array}$ \\
\hline$A d h-1$ seeds & & $\begin{array}{r}-0.2998^{*} \\
(0.1091)\end{array}$ & $\begin{array}{c}-0.2251^{*} \\
(0.1018)\end{array}$ & $\begin{array}{c}-0.1716 \\
(0.1753)\end{array}$ & $\begin{array}{c}-0.2262^{*} \\
(0.1329)\end{array}$ & $\begin{array}{r}-0.1037^{*} \\
(0.0940)\end{array}$ \\
\hline Lap-1 adults & $\begin{array}{l}-0.5407^{*} \\
< \\
<\end{array}$ & $\begin{array}{l}-0.5652^{*} \\
<^{(0.1870)}\end{array}$ & $\begin{array}{l}-0.6064^{*} \\
(0.1697) \\
=\end{array}$ & $\begin{array}{l}-0.2515 \\
(0.2765) \\
=\end{array}$ & $\begin{array}{l}-0.4747^{*} \\
=(0.2360) \\
=\end{array}$ & $\begin{array}{l}-0.4936^{*} \\
< \\
<\end{array}$ \\
\hline Lap-1 seeds & $\begin{array}{c}+0.0584 \\
(0.1999)\end{array}$ & $\begin{array}{c}-0.2092^{*} \\
(0.1104)\end{array}$ & $\begin{array}{r}-0.3267^{*} \\
(0.1440)\end{array}$ & $\begin{array}{c}-0.0757 \\
(0.1786)\end{array}$ & $\begin{array}{r}-0.3397^{*} \\
(0.1285)\end{array}$ & $\begin{array}{r}-0.1983^{*} \\
(0.0919)\end{array}$ \\
\hline Mean adults & $\begin{array}{l}-0.4600 \\
<^{(0.1582)}\end{array}$ & $\begin{array}{l}-0.3404 \\
(0.1486) \\
=\end{array}$ & $\begin{array}{l}-0.5154 \\
= \\
=\end{array}$ & $\begin{array}{l}-0.3698 \\
(0.1265) \\
<\end{array}$ & $\begin{array}{l}-0.4193 \\
(0.1775) \\
=\end{array}$ & $\begin{array}{l}-0.4750 \\
<0.2083) \\
<\end{array}$ \\
\hline Mean seeds & $\begin{array}{r}+0.0487 \\
(0.0189)\end{array}$ & $\begin{array}{c}-0.2356 \\
(0.0758)\end{array}$ & $\begin{array}{c}-0.1949 \\
(0.1225)\end{array}$ & $\begin{array}{c}-0.1576 \\
(0.0786)\end{array}$ & $\begin{array}{c}-0.1650 \\
(0.1908)\end{array}$ & $\begin{array}{r}-0.1359 \\
(0.0980)\end{array}$ \\
\hline
\end{tabular}

${ }^{*} P<0.05$, chi-square test (Li \& Horvitz, 1953).

$\nmid$ Equal in adults and seeds $(=)$, or smaller in the adults than in the seeds $(<)$, according to the $95 \%$ confidence intervals.

4 Negative assortative mating may occur (Brown et al., 1985).

5 Selection may favour heterozygote genotypes prior to the time of sampling (Brown et al., 1985).

The last two processes are the only ones that can produce the observed excess of heterozygotes in the progeny and hence we consider them to be the more important ones.

Negative fixation indices and negative $F_{\text {is }}$ were unexpected, especially for the seeds. We expected low but positive values for both, as we suspected some selfing and inbreeding because of poor seed dispersal (usually less than $3 \mathrm{~m} \mathrm{~L}$. E. Eguiarte et al. unpublished observations). A high outcrossing rate and long distance pollen dispersal can produce low fixation indices but not negative fixation indices, even if the parents present very negative fixation indices. Only if pollen moves long distances and seeds very little can a slight local excess of heterozygotes be generated (Prout, 1981); pollen and seed dispersal in $A$. mexicanum (L. E. Eguiarte et al. unpublished observations) seem to conform to this pattern. Negative fixation indices can also be generated by negative assortative mating (Hedrick, 1983) but we have no data on this process. We suggest, however, that the most important cause of the negative fixation indices is selection in favour of the more heterozygous individuals (Linhart et al., 1981; Waser, 1987). This hypothesis is supported by the increase in heterozygosity from seed to adults and the positive correlations between 
growth and heterozygosity for adults. Negative fixation indices have also been described for other plants, mainly long lived perennials (Linhart et al., 1981; Smyth \& Hamrick, 1984; Shea, 1987; Sampson et al., 1989) and in some animal populations (Schwartz \& Armitage, 1980).

The observed increase in heterozygote frequencies from seeds to adults could be generated by increased survivorship of the more heterozygous individuals. Similar increases have been reported in other tree

Table 10 Wright's $F$ statistics (Wright, 1965; Nei, 1987) for A. mexicanum in 1987 , for adults and seeds. $95 \%$ confidence intervals for the means in parentheses (Weir, 1990)

\begin{tabular}{lccc}
\hline Locus & \multicolumn{1}{l}{$F_{\text {is }}$} & $F_{\text {st }}$ & $F_{\text {it }}$ \\
\hline Mdh-1 adults & $-0.2014^{*}$ & $0.0318^{*}$ & $-0.1632^{*}$ \\
Mdh-1 seeds & $-0.0713^{*}$ & $0.0258^{*}$ & -0.0436 \\
6Pgd-1 adults & $-0.5756^{*}$ & $0.0563^{*}$ & $-0.4869^{*}$ \\
6Pgd-1 seeds & $-0.1004^{*}$ & $0.0048^{*}$ & $-0.0951^{*}$ \\
Pgi-1 adults & $-0.2432^{*}$ & 0.0141 & $-0.2257^{*}$ \\
Pgi-1 seeds & $-0.3081^{*}$ & $0.0046^{*}$ & $-0.3021^{*}$ \\
Adh-1 adults & $-0.5957^{*}$ & $0.0537^{*}$ & $-0.5100^{*}$ \\
Adh-1 seeds & $-0.2284^{*}$ & $0.0058^{*}$ & $-0.2212^{*}$ \\
Lap-2 adults & $-0.4687^{*}$ & $0.0422^{*}$ & $-0.4067^{*}$ \\
Lap-2 seeds & $-0.2341^{*}$ & $0.0044^{*}$ & $-0.2287^{*}$ \\
Mean adults & -0.4169 & 0.0396 & -0.3585 \\
& $(0.1623)$ & $(0.0152)$ & $(0.1369)$ \\
& $=\dagger$ & $>$ & $=$ \\
Mean seeds & -0.1885 & 0.0091 & -0.1781 \\
& $(0.0871)$ & $(0.0082)$ & $(0.0927)$ \\
\hline
\end{tabular}

${ }^{*} P<0.05$, chi-square test, for $F_{\text {is }}$ and $F_{\mathrm{it}}$ according to Li \& Horvitz (1953), for $F_{\text {st }}$ according to Workman \& Niswander (1970).

$\dagger$ Equal in adults and seeds $(=)$ or larger in the adults than in the seeds $(>)$, according to the $95 \%$ confidence intervals. species (Phillips \& Brown, 1977; El-Kassaby et al., 1987; O’Malley \& Bawa, 1987; Shea, 1987; O’Malley et al., 1988; Sampson et al., 1989).

Low genetic differentiation among Los Tuxtlas $A$. mexicanum plots could be expected because of the relatively short distance between them. Allelic frequency differences, genetic distances among different plots and $F_{\text {st }}$ were relatively small but significant. We also found significantly more differentiation in adults than in seeds. For instance there were significant differences in allelic frequencies in adults for most loci, but only for one locus for seeds. The increase in differentiation in adults may be due to adaptation to local conditions, and this differentiation is lowered in seeds because of the extensive pollen movement. It also means that the pollen gene pool is different from the local adult allelic frequencies.

Piñero \& Sarukhán (1982) and Sarukhán et al. (1984) demonstrated significant variation in growth and reproduction for $A$. mexicanum that could not be predicted from the ecological characteristics of their growing sites. We hypothesized that some of this variation could be explained by differences in heterozygosity among individuals. Accordingly, we found a positive relationship of individual heterozygosity with growth rate but not with fecundity. The relationship between growth and heterozygosity is weak. This may be expected given that the sampled loci are only a small part of the total genome and that growth is also affected by several ecological conditions such as available sunlight, soil and competition (Sarukhán et al., 1984). The lack of correlation between fecundity and individual heterozygosity may be due to a greater effect of the environment on fecundity than on growth (Piñero \& Sarukhán, 1982). A palm of a given genotype may grow at a more or less constant rate, using available surplus resources in reproduction. A similar pattern of positive correlations between heterozygosity

Table 11 Correlation matrix between number of heterozygous enzymes per individual (heterozygosity), the number of infructescences produced in 13 years, the increase in height of the trunk in 7 years (growth) and height in 1975 in A. mexicanum. Above the diagonal parametric Pearson correlations, below Spearman non-parametric correlations

\begin{tabular}{lllcc}
\hline & Heterozygosity & $\begin{array}{l}N \text { of } \\
\text { infructescences }\end{array}$ & Growth & $\begin{array}{l}\text { Height } \\
\text { in 1975 }\end{array}$ \\
\hline $\begin{array}{lllc}\text { Heterozygosity } \\
N \text { of infructescences }\end{array}$ & 0.153 & 0.153 & $0.307^{* *}$ & 0.020 \\
$\begin{array}{l}\text { Growth } \\
\text { Initial height }\end{array}$ & $0.318^{* *}$ & 0.087 & 0.083 & $0.422^{* *}$ \\
\hline
\end{tabular}

** $P<0.01$. 
with growth and lack of correlation with fecundity is found in many other perennial species (Mitton \& Grant, 1980, 1984; Ledig et al., 1983; Strauss, 1986; Govindaraju \& Dancik, 1987; Shea, 1987).

Higher growth rate may be correlated with general vigour in a given individual [thus more heterozygous individuals have lower mortality rates (Mitton \& Grant, 1984)], which explains the observed increase in heterozygous frequency from seeds to adults. In addition, rapid growth decreases the probability of death before reproduction by a falling branch or tree, one of the most important causes of death of $A$. mexicanum palms (Martínez-Ramos et al., 1988).

\section{Population genetics of trees}

Most studies indicate high genetic variation in tropical tree populations (Gan et al., 1977, 1981; Hamrick \& Loveless, 1986). Genetic variation levels in Astrocaryum mexicanum are similar to the average for tropical trees. The genetic estimates of outcrossing rates described for tropical trees (O'Malley \& Bawa, 1987; O'Malley et al., 1988; Moran et al., 1989), are high, as in our estimate for $A$. mexicanum. Fixation indices of tropical trees are either low or negative suggesting little inbreeding (Sytsma \& Schaal, 1985; O' Malley \& Bawa, 1987; O'Malley et al., 1988). Our results on both genetic identities and $F_{\text {st }}$ confirm the pattern of little spatial differentiation among plots that have been documented for several tropical species (Heywood \& Fleming, 1986; Buckley et al., 1988; Hamrick \& Loveless, 1989; Moran et al., 1989).

Apparently, tropical trees behave similarly to other trees, both angiosperms and gymnosperms. Most tree populations exhibit high levels of genetic variation (Hamrick et al., 1979; Hamrick \& Godt, 1989), high outcrossing rates (Schemske \& Lande, 1985; Brown et al., 1985), low fixation indices (Brown 1979; Eguiarte, 1990) and low genetic differentiation between sites (Loveless \& Hamrick, 1984).

\section{Tropical tree species diversity}

This study, along with data from other papers in the literature, indicates that tropical tree populations do not present any of the characteristics assumed by the non-adaptive hypothesis of tropical tree diversity (Corner, 1954; Baker, 1959; Federov, 1966; van Steenis, 1969). Rather they exhibit exactly the opposite. Astrocaryum mexicanum has an effective population size of at least 400 individuals and probably much larger (L. E. Eguiarte et al., unpublished observations). Data on genetic differentiation of other tropical trees $\left(G_{\text {st }}\right)$ also suggest very large effective population sizes and/or extensive gene flow (Hamrick \& Loveless, 1989). These large population sizes, coupled with more or less constant environments, would permit natural selection to be very effective and allow very fine ecological adaptation, as predicted by the microniches/equilibrium hypothesis of Dobzhansky (1950). However, the actual process of speciation in tropical trees remains to be explained.

\section{Implications for conservation}

The low densities usually present in tropical tree species indicate different conservation strategies from other organisms with similar population genetics (e.g. conifers). We suggest the following guidelines for the genetic conservation of tropical trees.

(a) Given the high genetic variation and low or negative fixation indices, we predict that inbreeding depression should be important in tropical trees populations. Selfing, inbreeding and small population numbers should be avoided in management strategies.

(b) Ecological preserves should be very large to maintain the high intrapopulation genetic variation and to avoid inbreeding and genetic drift.

(c) The low genetic differentiation between different sites shown by most tropical tree species suggests that for most species it will not be necessary to have a large number of natural preserves. However, smaller areas that can function as corridors and stepping-stones which may allow gene flow among sites, should also be preserved.

(d) Ex situ conservation strategies, based on seed and germplasm collection and preservation in gene banks, botanical gardens, etc., seem to be of little practical value for the conservation of the genetic diversity of tropical forest trees, given the high numbers of seed and parents needed to be collected to preserve at least part of the genetic variation present in a population (Brown \& Clegg, 1983), the high number of different species, and the problems in preserving, maintaining the viability and germinating tropical rain forest trees seeds (see Vázquez-Yanez \& Toledo, 1990). Only in situ conservation strategies seem to be of any real value for the conservation of tropical trees.

\section{Acknowledgements}

This work was supported by a grant from the CONACYT (México) and by doctoral scholarships from the CONACYT and the DGAPA, Universidad Nacional Autónoma de México to LEE. We thank V. Souza, A. M. Escalante, G. Coello, C. Domínguez, J. Nuñez and C. Cordero for enthusiastic field and/or laboratory assistance and critical discussions. $\mathrm{M}$. 
Martínez-Ramos permitted us access to data on individual growth and fecundity. M. T. Clegg, B. S. Gaut, G. Learn, E. Alvarez-Buylla, V. Souza, N. Ellstrand, S. Waller, A. Fontdevilla, A. Hoffman, A. Kamping, C. Martínez del Rio, and one anonymous reviewer, provided valuable comments on the manuscript. This paper owes much to the influence and ideas of Professor J. Sarukhán and we wish to acknowledge him.

\section{References}

BAKER, H. G. 1959. Reproductive methods as factors in speciation in flowering plants. Cold Spring Harbor Symp. Quant. Biol., 24, 177-190.

BAWA, K. S. 1990. Plant pollinator interactions in tropical rain forests. Ann. Rev. Ecol. Syst., 21, 399-422.

BONGERS, F, POPMA, J., MEAVE DEL CASTILLO, J. AND CARABIAS, J. 1988. Structure and floristic composition of the lowland rain forest of Los Tuxtlas, Mexico. Vegetatio, 74, 55-80.

BRown, A. H. D. 1979. Enzyme polymorphism in plant populations. Theor. Popul. Biol., 15, 1-42.

BROWN, A. H. D., BARRETT, S. H. C. AND MORAN, G. F. 1985. Mating system estimation in forest trees: models, methods and meanings. In: Gregorius, H. R. (ed.) Population Genetics in Forestry. Springer-Verlag, Berlin pp. 32-49.

BROWN, B. A. AND CLEGG, M. T. 1983. Isozyme assessment of plant genetic resources. Isozymes: Curr. Top. Biol. Med. Res., 11, 285-295.

BROWN, A. H. D. AND WEIR, B. S. 1983. Measuring genetic variability in plant populations. In: Tanksley, S. D. and Orton, T. J. (eds) Isozymes in Plant Genetics and Breeding. Part A. Elsevier, Amsterdam, pp. 219-239.

BUCKLEY, D. P., O'MALLEY, D. M., ASPIT, V., PRANCE, G. T. AND BAWA, K. S. 1988. Genetics of Brazil nut (Bertholletia excelsa Humb. \& Bonpl.: Lecythidaceae) 1: Genetic variation in natural populations. Theor. Appl. Genet., 76, 923-928.

BURQUEZ, A., SARUKhan, J. AND PEDROZA, A. L. 1987. Floral biology of a primary forest palm, Astrocaryum mexicanum Liebm. Bot. J. Linn. Soc., 94, 407-419.

CONNELL, J. H. 1978. Diversity in tropical rain forest and coral reefs. Science, 199, 1302-1309.

CORNER, E. J. H. 1954. The evolution of tropical forest. In: Huxley, J., Hardy, A. C. H. and Ford, E. B. (eds) Evolution as a Process. George Allen and Unwin, London, pp. 34-46.

DENSLOW, J. s. 1987. Tropical rainforest gaps and tree species diversity. Ann. Rev. Ecol. Syst., 18, 431-451.

Dobzhansky, t. 1950. Evolution in the tropics. Am. Sci., 32, 209-221.

egularte, L. E. 1990. Genética de poblaciones de Astrocaryum mexicanum Liebm. en Los Tuxtlas, Veracruz. Ph.D. thesis. Universidad Nacional Autónoma de México.

EGUiARTE, L. E. AND PIN̂ERO, D. 1990. Genética de la conservación: leones vemos, genes no sabemos. Ciencias, Número especial 4, 34-47.

EL-KASSABY, Y. A., MEAGHER, M. D., PARKINSON, J. AND PORTLOCK, F. T. 1987. Allozyme inheritance, heterozygosity and outcrossing rate among Pinus monticola near Ladysmith, British Columbia. Heredity, 58, 173-181.
ELlSTRAND, N. AND DEVLin, B. 1989. Transmission genetics of isozyme loci in Raphanus sativus (Brassicaceae): stressdependent non-mendelian segregation. Am. J. Bot., 76, 40-46.

FEDEROV, A. A. 1966. The structure of the tropical rain forest and speciation in the humid tropics. J. Ecol., 54, 1-11.

FRANKEL, O. H. AND SOULE, M. E. 1981. Conservation and Evolution. Cambridge University Press, Cambridge.

FRANKLIN, I. R. 1980. Evolutionary changes in small populations. In: Soulé, M. E. and Wilcox, B. A. (eds) Conservation Biology: An Evolutionary Ecological Perspective. Sinauer, Sunderland, MA, pp. 135-150.

GAN, Y. Y., ROBERTSON, F. W. AND ASHTON, P. S. 1977. Genetic variation in wild populations of rain-forest trees. Nature, 269, 323-325.

GAN, Y. Y., ROBERTSON, F. W. AND SOEPADMO, E. 1981. Isozyme variation in some tropical trees. Biotropica, 13, 20-28.

GOVINDARAJU, D. R. AND DANCIK, B. P. 1987. Allozyme heterozygosity and homeostasis in germinating seed of jack pine. Heredity, 59, 279-283.

HAMRICK, J. L. AND GODT, M. J. W. 1989. Allozyme diversity in plants species. In: Brown, A. H. D., Clegg, M. T., Kalher, A. L., and Weir B. S. (eds), Plant Population Genetics, Breeding and Genetic Resources. Sinauer, Sunderland, MA, pp. 42-63.

HAMRICK, J. L., LINHART, Y. B. AND MITTON, J. B. 1979. Relationships between life history characteristics and electrophoretically detectable genetic variation in plants. Ann. Rev. Eco. Syst., 10, 173-200.

HAMRICK, J. L. AND LOVELESS, M. D. 1986. Isozyme variation in tropical trees: procedures and general results. Biotropica, 18, 201-207.

HAMRICK, J. L. AND LOVELESS, M. D. 1989. The genetic structure of tropical tree populations: associations with reproductive biology. In: Bock, J. H. and Linhart, Y. B. (eds), The Evolutionary Ecology of Plants. Westview Press, Boulder, pp. 129-146.

HEDRICK, P. w. 1983. Genetics of Populations. Science Books Intl., Boston.

HEYwood, J. S. AND FLEMING, T. H. 1986. Patterns of allozyme variation in three tropical species of Piper. Biotropica, 18, 208-213.

HUBBELL, S. P. 1979. Tree dispersion, abundance, and diversity in a tropical dry forest. Science, 203, 1299-1309.

JANZEN, D. H. 1970. Herbivores and the number of tree species in tropical forest. Am. Nat., 104, 501-528.

LEDIG, F. T., GURIES, R. P. AND BONEFELD, B. A. 1983. The relation of growth and heterozygosity in pitch pine. Evolution, 37, $1227-1238$.

LI, C. C. AND HORVITZ, D. G. 1953. Some methods of estimating the inbreeding coefficient. Am. J. Hum. Genet., 5, $107-117$.

LINHART, Y. B., MITTON, J. B., STURGEON, K. B. AND DAVIS, M. L. 1981. Genetic variation in space and time in a population of ponderosa pine. Heredity, 46, 407-426.

LOVELESS, M. D. AND HAMRICK, J. L. 1984, Ecological determinants of genetics structure in plant populations. Ann. Rev. Ecol. Syst., 15, 65-95.

MARTINEZ-RAMOS, M., ALVAREZ-BUYLLA, E., SARUKHAN, J. AND PINEERO, D. 1988. Treefall age determination and gap 
dynamics in a tropical forest. J. Ecol., 76, 700-716.

MITTON, J. B. AND GRANT, M. C. 1980 . Observations on the ecology and evolution of quaking aspen, Popolus tremuloides in the Colorada Front Range. Am. J. Bot., 67, 200-209.

MITTON, J. B. AND GRANT, M. C. 1984. Associations among protein heterozygosity, growth rate, and developmental homeostasis. Ann. Rev. Ecol. Syst., 15, 479-499.

MORAN, G. F., MUONA, O. AND BELL, J. C. 1989. Breeding systems and genetic diversity in Acacia auriculiformis and $A$. crassicarpa. Biotropica, 21, 250-256.

NEI, M. 1972. Genetic distance between populations Am. Nat., 105, 385-398.

NEI, M. 1987. Molecular Evolutionary Genetics. Columbia University Press, New York.

O'MALLEY, D. M. AND BAWA, K. s. 1987. Mating systems of a tropical rain forest tree species. Am. J. Bot., 74, 1143-1149.

O'MALLEY, D. M., BUKLEY, D. P., PRANCE, G. T. AND BAWA, K. S. 1988. Genetics of Brazil nut (Bertholletia excelsa) Humb. \& Bonpl.: Lecythidaceae) 2: Mating system. Theor. Appl. Genet., 76, 929-932.

PHILLIPS, M. A. AND BROWN, A. H. D. 1977. Mating systems and hybridity in Eucalyptus pauciflora. Aust. J. Biol. Sci., 30, 337-344.

PINERO, D. AND EGUIARTE, L. E. 1988. The origin and biosystematic status of Phaseolus coccineus ssp. polyanthus: electrophoretic evidence. Euphytica, 37, 199-203.

PINEERO, D., MARTINEZ-RAMOS, M., MENDOZA, A., ALVAREZ-BUYLLA, E. AND SARUKhan, J, 1986. Demographic studies in Astrocaryum mexicanum and their use in understanding community dynamics. Principes, 30, 108-116.

PIÑERO, D., MARTINEZ-RAMOS, M. AND SARUKHAN, J. 1984. A population model of Astrocaryum mexicanum and a sensitivity analysis of its finite relative rate of increase. J. Ecol. 72, 977-991.

PIÑERO, D. AND SARUKHAN, J. 1982. Reproductive behaviour and its individual variability in a tropical palm, Astrocaryum mexicanum. J. Ecol., 72, 977-991.

PiÑERO, D., SARUKHAN, J. AND GONZALEZ, E, 1977. Estudios demográficos en plantas. Astrocaryum mexicanum Liebm. Estructura de las poblaciones. Biol. Soc. Bot. Méx., 37, 69-118.

PRoUT, T. 1981. A note on the Island Model with sex dependent migration. Theor. Appl. Genet., 59, 327-332.

RASMUSSEN, D. I. 1964. Blood group polymorphisms and inbreeding in natural populations of the deer mouse, Peromyscus maniculatus. Evolution, 18, 219-229.

RICHARDSON, B. J., BAVERSTOCK, P. R. AND ADAMS, M. 1986. Allozyme Electrophoresis. Academic Press, Melbourne.

RITLAND, K. 1983. Estimation of mating systems. In: Tanksley, S. D. and Orton, T. J. (eds) Isozymes in Plant Genetics and Breeding. Part A. Elsevier, Amsterdam. pp. 289-302.

RITLAND, K. 1990. A series of FORTRAN computer programs for estimating plant mating systems. J. Hered., 81, 235-237.

RITLAND, K. AND JAIN, S. K. 1981. A model for the estimation of the outcrossing and gene frequencies using $n$ independent loci. Heredity, 47, 35-52.

SAMPSON, J. E., HOPPER, S. D. AND JAMES, S. H. 1989. The mating system and population genetic structure in a bird- pollinated mallee, Eucalyptus rhodantha. Heredity, 63, 383-393.

SARUKHAN, J., MARTINEZ-RAMOS, M. AND PIÑERO, D. 1984. The analysis of demographic variability at the individual level and its population consequences. In: Dirzo, R. and Sarukhán, J. (eds) Plant Population Ecology. Sinauer, Sunderland, MA, pp. 83-106.

SCHEMSKE, D. W. AND LANDE, R. L. 1985. The evolution of selffertilization and inbreeding depression in plants. II. Empirical observations. Evolution, 39, 41-52.

SCHOEN, D. J. AND CLEGG, M. T. 1984. Estimation of mating system parameters when outcrossing events are correlated. Proc. Natl. Acad. Sci., U.S.A ., 81, 5258-5262.

SCHOEN, D. J. AND CLEGG, M. T. 1986. Monte Carlo studies of plant mating system estimation models: the one-pollen parent and mixed mating models. Genetics, 112 , 927-945.

SCHWARTZ, O. A. AND ARMITAGE, K. B. 1980. Genetic variation in social mammals: the marmot model. Science, 207, 665-667.

SELANDER, R. K., CAUGANT, D. A., OCHMAN, H., MUSER, J. M., GILMOUR, M. N. AND WHITTAM, T. s. 1986. Methods of multiloci enzyme electrophoresis for bacterial population genetics and systematics. Appl. Environ. Microbiol., 5, 873-884.

SHEA, K. L. 1987. Effects of population structure and cone production on outcrossing rates in Engelmann Spruce and Subalpine Fir. Evolution, 41, 124-136.

SMYTH, C. A. AND HAMRICK, J. L. 1984. Measurement of outcrossing in natural population of musk thistle, Carduus nutans L. J. Hered., 75, 303-307.

SOKAL, R. R. AND ROHLF, J. F. 1969. Biometry W. H. Freeman, San Francisco.

STEENIS, C. G. G. J. VAN. 1969. Plant speciation in Malesia with special reference to the theory of non-adaptive saltatory evolution. Biol. J. Linn. Soc., 1, 97-133.

STRAUSS, S. H. 1986. Heterosis at allozyme loci under inbreeding and cross breeding in Pinus attenuata. Genetics, 113, 115-134.

SYTSMA, K. J. AND SCHAAL, B. A. 1985. Genetic variation, differentiation and evolution in a species complex of tropical shrubs based on isozymic data. Evolution, 39, 582-593.

VALLEJos, C. E. 1983. Enzyme activity staining. In: Tanksley, S. D. and Orton, T. J. (eds) Isozymes in Plant Genetics and Breeding. Part A. Elsevier, Amsterdam. pp. 469-516.

VAZQUEZ-YANES, C. AND TOLEDo, A. J. R. 1990. Bases ecofisiológicas de la conservación de semillas. Bol. Soc. Bot. Méx., 49, 61-69.

WASER, N. M. 1987. Spatial genetic heterogeneity in a population of the montane perennial plant Delphinium nelsonii. Heredity, 58, 249-256.

WEIR, B. S. 1990. Genetic Data Analysis. Sinauer, Sunderland, MA.

WORKMAN, P. L. AND NISWANDER, J. L. 1970. Population studies on southwestern Indian tribes. II. Local genetic differentiation in the Papago. Am. J. Hum. Genet., 22, 24-49.

WRIGHT, s. 1965. The interpretation of population structure by F-statistics with special regard to system of mating. Evolution, 19, 355-420. 